\title{
Correction to: Prevalence of Enterobacteriaceae in Wild Long-Tailed Macaques (Macaca fascicularis) in Thailand
}

\section{Krishna N. Balasubramaniam ${ }^{1}$ (D) - Suchinda Malaivijitnond ${ }^{2,3} \cdot$ Taratorn Kemthong ${ }^{2}$ - Suthirote Meesawat ${ }^{2,3}$ - Yuzuru Hamada ${ }^{4}$. Saharuetai Jeamsripong ${ }^{5}$ - Jutanat Srisamran ${ }^{5} \cdot$ Mullika Kuldee $^{5}$. Varangkana Thaotumpitak $^{5}$ - Brenda McCowan ${ }^{1,6} \cdot$ Edward Atwill $^{1}$}

Published online: 6 May 2021

(C) The Author(s) 2021

\section{Correction to: International Journal of Primatology https://doi.org/10.1007/s10764-021-00209-3}

The original version of this article unfortunately contained mistakes. First, in the "Acknowledgments" section, another funding source [Thailand Research Fund Senior Scholar (grant number RTA6280010)] should be acknowledged for this study. Second, in the "Author Contributions" section, only the contributions of the first and the last two authors were listed.

The online version of the original article can be found at https://doi.org/10.1007/s10764-021-00209-3

Krishna N. Balasubramaniam

krishnanatarajan@ucdavis.edu

1 Department of Population Health \& Reproduction, School of Veterinary Medicine, University of California, Davis, Davis, CA, USA

2 National Primate Research Center of Thailand-Chulalongkorn University, Saraburi, Thailand

3 Department of Biology, Faculty of Science, Chulalongkorn University, Bangkok, Thailand

4 Evolutionary and Morphology Section, Primate Research Institute of Kyoto University, Inuyama, Japan

5 Department of Veterinary Public Health, Faculty of Veterinary Science, Research Unit in Microbial Food Safety and Antimicrobial Resistance, Chulalongkorn University, Pathumwan, Bangkok, Thailand

6 Neuroscience and Behavior Unit, California National Primate Research Center, University of California, Davis, Davis, CA, USA 
The updated version of these statements are presented below:

Acknowledgements We wish to thank the following personnel for their assistance: Nopparat Kongsombat, Chanatip Kraitat, Poompat Phadphon, and Prangmas Kumpai. We are grateful to the following organizations in Thailand for their support and cooperation: National Research Council of Thailand and Department of National Parks, Wildlife and Plant Conservation. The projected was funded by UC Davis faculty discretionary funds (B. McCowan and E. Atwill), and by the Thailand Research Fund Senior Scholar (grant number RTA6280010) awarded to S. Malaivijitnond.

Author Contributions KNB, supervised by EA and BJM, designed the study and its aims, analyzed the data, and wrote the manuscript. SM, SJ, and $\mathrm{YH}$ all participated in designing the study, supervised the data collection and processing in Thailand, and contributed to writing various sections of the manuscript. TK, SM, JS, MK, and VT participated all helped collect macaque demographic data, processed macaque samples for the screening and confirmation of bacterial pathogens, and contributed to writing the manuscript.

The original article has been corrected.

Open Access This article is licensed under a Creative Commons Attribution 4.0 International License, which permits use, sharing, adaptation, distribution and reproduction in any medium or format, as long as you give appropriate credit to the original author(s) and the source, provide a link to the Creative Commons licence, and indicate if changes were made. The images or other third party material in this article are included in the article's Creative Commons licence, unless indicated otherwise in a credit line to the material. If material is not included in the article's Creative Commons licence and your intended use is not permitted by statutory regulation or exceeds the permitted use, you will need to obtain permission directly from the copyright holder. To view a copy of this licence, visit http://creativecommons.org/licenses/by/4.0/. 